\title{
Hepatocyte 'priming' and increase in transforming growth factor-\$1 mRNA expression are delayed in hypothyroid versus euthyroid rats during liver regeneration
}

\author{
LOREDANA MORO, ELDA PERLINO, ERSILIA MARRA and MARGHERITA GRECO
}

Institute of Biomembranes and Bioenergetics (IBBE), National Research Council (CNR), Bari, Italy

Received October 6, 2005; Accepted November 21, 2005

\begin{abstract}
Hypothyroidism decreases liver weight and delays the compensatory liver growth after partial hepatectomy $(\mathrm{PH})$ as compared with the euthyroid condition. The aim of this study was to investigate, in hypothyroid rats, the mRNA expression of genes modulating these effects, focusing on c-fos and c-myc, hallmarks of hepatocyte 'priming', and on transforming growth factor- $\beta 1$ (TGF- $\beta 1$ ) and its receptor, the transforming growth factor- $\beta 1$ receptor-type II (TßR-II), negative regulators of liver growth. Euthyroid and hypothyroid male Wistar rats underwent $70 \% \mathrm{PH}$ and total RNA was isolated from frozen liver samples removed at basal state and during regeneration, $0-144 \mathrm{~h}$ after surgery. In this study, we show for the first time that, in the basal liver state, hypothyroidism increased TGF- 31 and TßR-II mRNA levels by $45 \%$ and $30 \%$, respectively, as compared with the euthyroid condition and, after $\mathrm{PH}$, resulted in a $\sim 12$-h delay in the activation of c-fos and c-myc mRNA expression. Moreover, the increase in TGF- $\beta 1$ mRNA levels, detected 24-48 h after $\mathrm{PH}$ in euthyroid rats, was delayed by $72 \mathrm{~h}$ in hypothyroid rats, occurring when a concomitant reduction in TBR-II was measured. These results suggest that, in hypothyroid rats, at the basal liver level, the increase in mRNA expression of genes that negatively regulate liver growth might be involved in the decrease in liver weight and that, after PH, the delay of hepatocyte 'priming' and coordinated changes in mRNA expression of negative regulators of liver regeneration might be involved in delaying the regenerative process.
\end{abstract}

\section{Introduction}

The regeneration of the rat liver following two-thirds $\mathrm{PH}$ is one of the most useful models for studying the cellular and subcellular changes occurring in vivo in different phases of normal and pathological cell proliferation because of the

Correspondence to: Dr Margherita Greco, Institute of Biomembranes and Bioenergetics, National Research Council, Via Amendola 165/A, I-70126 Bari, Italy

E-mail: m.greco@ibbe.cnr.it

Key words: hypothyroidism, liver regeneration, c-fos, c-myc, TGF- $\beta$, TßR-II, mRNA expression high synchronism of the first cell cycle, the timing of which has been precisely defined in physiological conditions (1). Hepatocyte proliferation following $\mathrm{PH}$ begins with the 'priming' of quiescent mature hepatocytes from a resting state (G0) to the prereplicative G1 phase of the cell cycle, which lasts for 12-14 h. The pre-replicative phase is followed by DNA synthesis, which peaks 22-24 $\mathrm{h}$ after $\mathrm{PH}$, and by mitosis $6-8 \mathrm{~h}$ later (2). Thereafter, the liver mass is gradually recovered, and the regenerative process is complete $96 \mathrm{~h}$ after $\mathrm{PH}$ (3). The regenerative process involves metabolic and ultrastructural changes (3-5) and, in order to be precisely carried out, multiple hepatic cell types must proliferate in a coordinated fashion (6). A coordinated balance of positive and negative controls, through selective sequence of gene expression, allows the normal regenerative process (7). Following $\mathrm{PH}$, quiescent mature hepatocytes are 'primed' to re-enter the cell cycle. The 'priming' process appears to be triggered by extracellular cytokines (interleukin- 6 and tumor necrosis factor- $\alpha$ ) and is characterized by the expression of immediate early genes (8).

The genes induced immediately after $\mathrm{PH}$ include some proto-oncogenes, such as c-fos and c-myc, which are responsible for hepatocyte 'priming' and are believed to act as transcription factors for genes active later in the G1 phase of the cell cycle $(6,7)$. Negative regulatory influences are induced later by specific growth inhibitors, such as TGF- 31 , to stop the regenerative process when the liver mass has been restored $(9,10)$. Signaling by TGF- $\beta 1$ occurs through TßR-II (11) and arrests the cell cycle in G1 phase by stimulating the production of the cyclin-dependent protein kinase inhibitors and by inhibiting the function or production of essential cell cycle regulators (12).

Several hormones appear to be essential for liver regeneration, including thyroid hormone $\left(\mathrm{T}_{3}\right)(1,2) . \mathrm{T}_{3}$ is a powerful inducer of hepatocyte proliferation $(13,14)$ and its mitogenic capacity has been used for gene therapy experiments and repopulation of hepatocytes $(15,16) . \mathrm{T}_{3}$ plays a major role in hepatic mitochondrial maturation and metabolism as it regulates the mitochondrial membrane function and the expression of both mitochondrial and nuclear genes (17-19). Additionally, $\mathrm{T}_{3}$ regulates the expression of nuclear genes involved in the modulation of the cell cycle (20). It has been recently shown that $T_{3}$ plays a role in the compensatory liver growth that follows partial surgical removal of the liver (21). On the other hand, either thyroidectomy or chemically- 
induced hypothyroidism reduces the capacity to recover liver mass after PH $(21,22)$ and causes the inhibition of DNA synthesis (23) and mitotic activity $(22,23)$.

We have recently demonstrated that hypothyroidism decreases the liver weight and delays the regenerative process after PH $(17,21)$. However, the molecular mechanisms responsible for these events are largely uncharted. In this study, we investigated whether hypothyroidism affects the mRNA expression of genes that can modulate liver growth and regeneration, focusing on hallmarks of hepatocyte 'priming', such as c-fos and c-myc $(6,7)$, and on negative regulators of hepatocyte proliferation, such as TGF- $\beta 1$ and TßR-II (9-11).

\section{Materials and methods}

Animals. Male Wistar rats (200-250 g) were housed in a temperature-controlled room $\left(22^{\circ} \mathrm{C}\right)$ with food and water ad libitum. Three independent series of rats were used. For each series, rats were divided into two groups. The first group (group 1) was given ordinary drinking water (euthyroid); the second group (group 2) in addition was given $0.1 \%$ (wt/vol) 6-n-propyl-2-thiouracil (PTU) in drinking water for 21 days (hypothyroid) (21). The transition from euthyroidism to hypothyroidism was evaluated by measuring $\mathrm{T}_{3}$ serum levels (21). PH was performed with removal of the median and left lateral lobes of the liver of euthyroid and hypothyroid rats, as previously described (21) and the excised tissue was used as non-regenerating liver at basal state. After surgery, rats were kept on a standard diet until they were sacrificed. Blood samples were collected at the time of sacrifice, 0-144 h after $\mathrm{PH}$, for estimation of $\mathrm{T}_{3}$ serum levels. The livers were removed, weighed, kept in liquid nitrogen and used for RNA extraction. All operations were carried out under sterile conditions. The animals received humane care and the study was approved by the State Commission on Animal Experimentation.

RNA extraction and Northern blot analysis. Total cellular RNA was isolated from frozen tissue samples using the guanidinium isothiocyanate-cesium chloride procedure (24). Northern blotting analysis was carried out as described previously (25). Briefly, RNA samples (25 $\mu \mathrm{g} /$ lane) were separated on formaldehyde-agarose gels and blotted onto nylon membranes (Hybond $\mathrm{N}^{+}$; Amersham, Milan, Italy). The blots were hybridized with cDNA probes, previously labeled with $\left[\alpha^{-}{ }^{32} \mathrm{P}\right] \mathrm{dCTP}(3,000 \mathrm{Ci} / \mathrm{mmol}$; NEN Life Science Products, Boston, MA) by random primer extension (Megaprime DNA labeling kit; Amersham), for $20 \mathrm{~h}$ at $42^{\circ} \mathrm{C}$. The filters were washed once with $2 \mathrm{X}$ SSPE, $0.1 \%$ SDS for $10 \mathrm{~min}$ at room temperature; then with $1 \mathrm{X} \mathrm{SSPE}, 0.1 \% \mathrm{SDS}$ at $42^{\circ} \mathrm{C}$; followed by several washes in $0.1 \mathrm{X} \mathrm{SSPE}, 0.1 \% \mathrm{SDS}$, at $65^{\circ} \mathrm{C}$; and finally exposed, at $-80^{\circ} \mathrm{C}$ overnight or longer, to Kodak X-Omat AR 5 film (Kodak, Rochester, NY). Radiolabeled probes were generated using human c-fos DNA obtained from the recombinant plasmid, pBR322-c-fos [pcfos (human)-1] (26); the human c-myc cDNA cleaved from the recombinant plasmid, pRyc-7.4 (27); the human TGF-ß1 cDNA (28) or the human TBR-II cDNA (29). Quantitative analysis was performed by densitometric scanning of the autoradiographs using a GS-700 Imaging densitometer (Bio-Rad, Richmond, CA); multiple exposures of the same Northern blots in a linear range were performed. Hybridization with a $1.3-\mathrm{kb}$ cDNA fragment for 28S rRNA (30) was used as a control to determine the integrity of RNA and equality of loading in each lane.

Statistical analysis. The statistical significance of differences between groups was determined by one-way ANOVA followed by a Student-Newman-Keuls test. Comparison between independent means was performed using the Student's t-test.

\section{Results}

Hypothyroidism increases TGF- $\beta 1$ and T $\beta R-I I m R N A$ expression in rat liver. The administration of PTU to euthyroid rats for 21 days induced hypothyroidism, with $\mathrm{T}_{3}$ serum levels of $86 \pm 5 \mathrm{ng} / \mathrm{dl}$ versus $182 \pm 11 \mathrm{ng} / \mathrm{dl}$ of euthyroid controls $(\mathrm{P}<0.03)$, and resulted in a reduced liver weight $(7.5 \pm 0.4 \mathrm{~g})$ as compared with euthyroid controls $(12.1 \pm 0.8 \mathrm{~g})(\mathrm{P}<0.01)$, as previously reported (17). The mRNA expression levels of genes regulating liver growth and proliferation, i.e. c-fos, c-myc, TGF- 31 and TßR-II, were measured in the liver of hypothyroid rats at the basal state and compared with euthyroid controls by Northern blotting (Fig. 1A). c-fos and c-myc mRNAs were undetectable both in hypothyroid and euthyroid rats, at variance with TGF- $\beta 1$ and TßR-II. The values of TGF- 31 and TßR-II mRNA levels were related to 28S RNA, accounting for RNA loading in each sample. Both TGF- 1 and TßR-II levels were higher $(\mathrm{P}<0.01)$ in hypothyroid than in euthyroid animals, by $45 \pm 4 \%$ and $30 \pm 5 \%$, respectively (Fig. 1B).

Hypothyroidism delays the mRNA expression of immediate early genes during liver regeneration. 'Priming' characterizes the initiation of hepatocyte proliferation after $\mathrm{PH}$ (31). To investigate whether the 'priming' of hepatocytes was altered as a result of hypothyroidism, we measured the pattern of expression of the immediate early response genes, $c$-fos and $c-m y c$, during the regenerative process. First we confirmed that, during liver regeneration, $\mathrm{T}_{3}$ serum levels in hypothyroid rats remained lower than in euthyroid controls, as previously reported (21). Then, we measured steady-state levels of c-fos and c-myc mRNAs by Northern blot analysis of total RNA isolated from livers at different times after PH (Fig. 2A). c-fos and c-myc mRNA levels in all samples were related to the 28S RNA levels, accounting for RNA loading in each sample, and calculated as a percentage of the maximal levels of expression detected in euthyroid rats during the time course experiment. Fig. 2B shows the c-fos and c-myc mRNA expression profiles in the livers of euthyroid and hypothyroid rats. The mRNA expression of the two genes at time of surgery, i.e. in non-regenerating liver, was undetectable. After surgery, the mRNA expression of these genes was activated both in euthyroid and hypothyroid rats at different times. In fact, in euthyroid rats, c-fos and c-myc were expressed within $0.5 \mathrm{~h}$ following $\mathrm{PH}$, and reached peaks of expression at $0.5-3 \mathrm{~h}$ and at $48 \mathrm{~h}$, consistent with previous reports $(31,32)$. On the contrary, in hypothyroid rats, c-fos mRNA was detected at $12 \mathrm{~h}$, and its expression was prolonged for up to $72 \mathrm{~h}$, at which point it reached levels comparable to those detected in euthyroid rats at $0.5 \mathrm{~h}$. Another peak of c-fos mRNA expression 
A

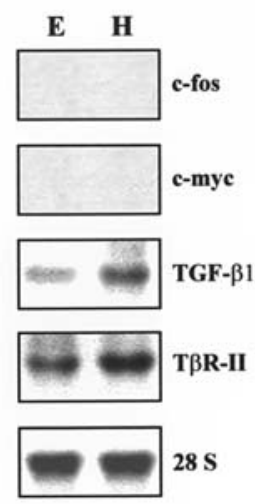

B

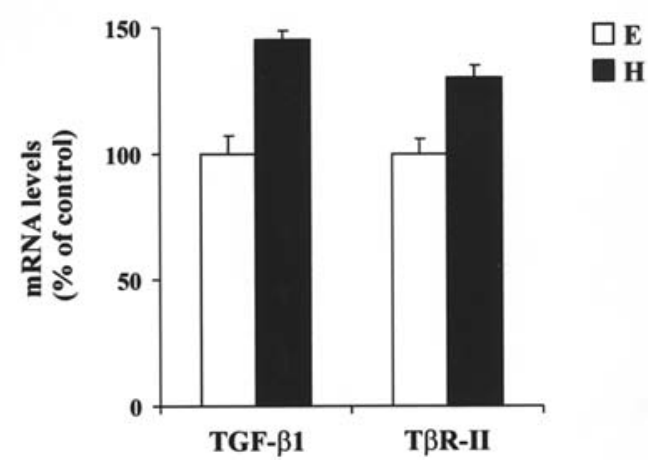

Figure 1. c-fos, c-myc, TGF-B1 and TBR-II mRNA expression in the liver of euthyroid (E) and hypothyroid (H) rats. (A) Northern blot analysis for c-fos, cmyc, TGF- $\beta 1$ and TBR-II mRNA expression. Hybridization with a 28S rRNA probe was used as control to determine the equality of loading in each lane. (B) A quantification of TGF-ß1 and TßR-II mRNA levels in hypothyroid rat liver is reported as the percentage of mRNA levels in euthyroid rat liver (control), set at 100. The mean values \pm SE of three different experiments performed on samples obtained from three different animals for each experimental group are reported.

$\mathbf{A}$

E

Time

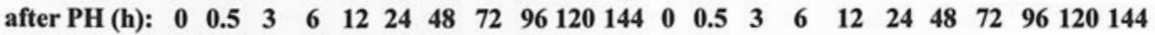

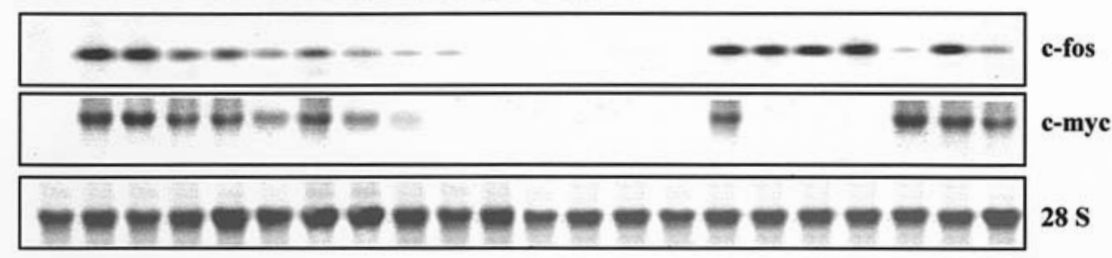

$\mathbf{B}$

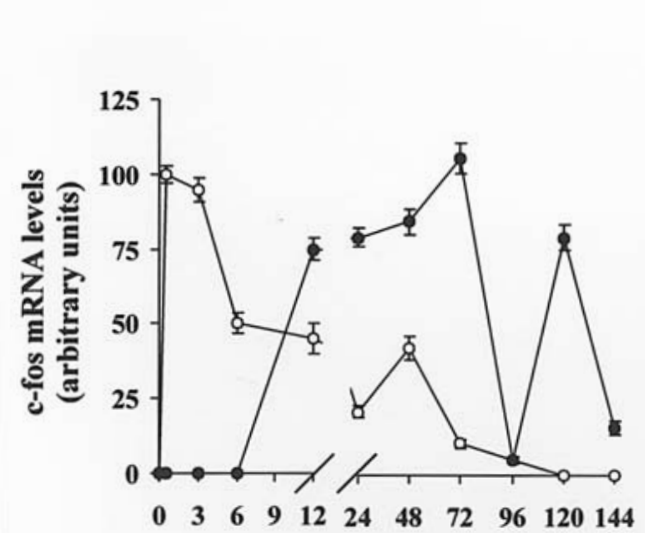

Time after PH (h)

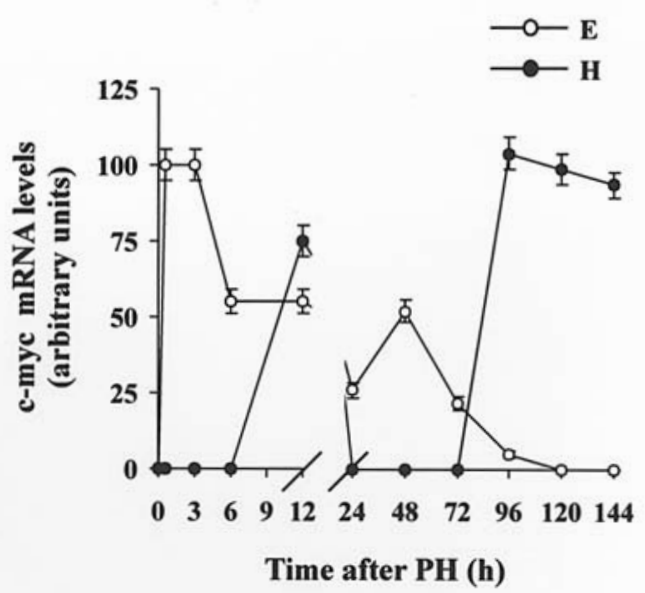

Time after PH (h)

Figure 2. c-fos and c-myc mRNA expression in the liver of euthyroid (E) and hypothyroid (H) rats after PH. (A) Northern blot analysis for c-fos and c-myc expression at 0-144 $\mathrm{h}$ of liver regeneration. Hybridization with a $28 \mathrm{~S}$ rRNA probe was used as control to determine the equality of loading in each lane. (B) cfos and c-myc mRNA expression levels in the livers of euthyroid or hypothyroid rats after PH were reported as the percentage of maximal levels detected during liver regeneration in euthyroid rats, set at 100 . The mean values $\pm \mathrm{SE}$ of three different experiments performed on samples obtained from three different animals for each experimental group are reported.

was detected at $120 \mathrm{~h}$ that reached $75 \pm 4 \%$ of the control. Similar to c-fos, a biphasic expression profile was found for c-myc mRNA with peaks at $12 \mathrm{~h}(74 \pm 5 \%$ of the control;
$\mathrm{P}<0.001)$ and at $96 \mathrm{~h}$, at which point $\mathrm{c}-\mathrm{myc}$ mRNA levels reached values comparable to those detected at $0.5-3 \mathrm{~h}$ in euthyroid rats. 
$\mathbf{A}$

E

H

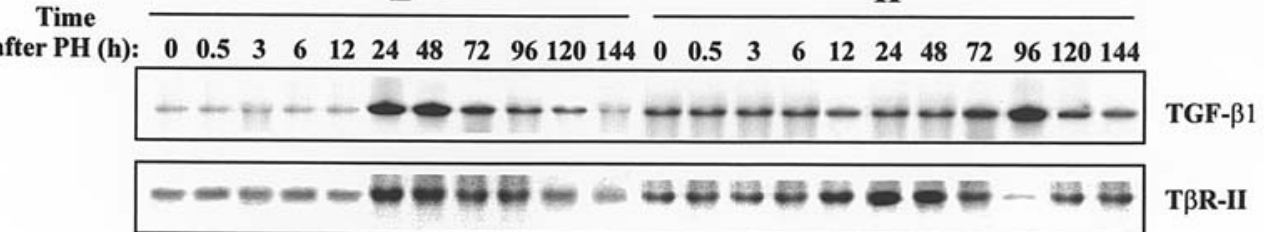

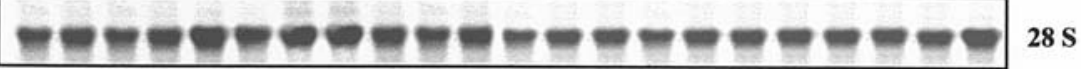

B
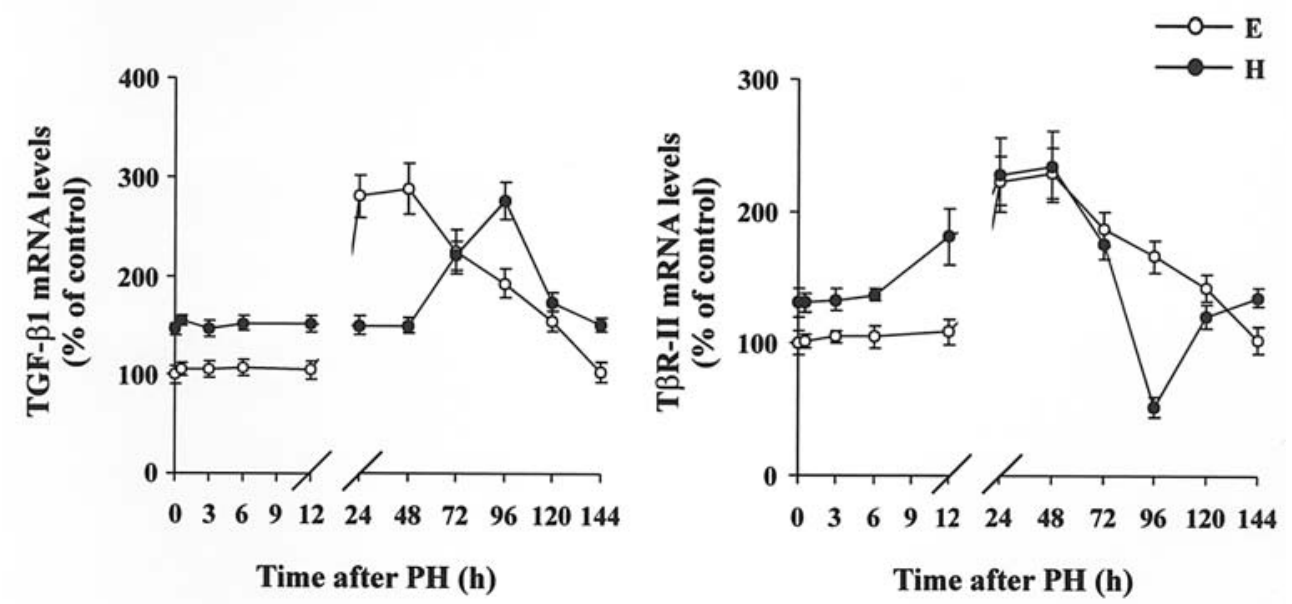

Figure 3. TGF-ß1 and TßR-II mRNA expression in the liver of euthyroid (E) and hypothyroid (H) rats after PH. (A) Northern blot analysis for TGF-ß1 and TßR-II mRNA expression. Hybridization with a $28 \mathrm{~S}$ rRNA probe was used as control to determine the equality of loading in each lane. (B) TGF- 31 and TBRII mRNA expression levels in the livers of euthyroid and hypothyroid rats after PH were reported as a percentage of the mRNA levels in euthyroid rats at $0 \mathrm{~h}$ (control), set at 100. The mean values \pm SE of three different experiments performed on samples obtained from three different animals for each experimental group are reported.

Hypothyroidism affects TGF- $\beta 1$ and T $\beta R$-II $m R N A$ expression during liver regeneration. The regenerative response after $\mathrm{PH}$ stops abruptly when the liver mass has been restored $(1,2,6)$. To investigate the effect of hypothyroidism on the signals involved in the arrest of hepatocyte proliferation, the pattern of expression of TGF- 31 and TßR-II mRNAs during liver regeneration was measured by Northern blot analysis on the same blots used to evaluate c-fos and c-myc mRNA expression (Fig. 3A). TGF-ß1 and TßR-II mRNA expression levels were calculated as a percentage of the levels of expression detected in the excised tissue at surgery time. Fig. 3B shows the TGF- 31 and TßR-II mRNA expression profiles in euthyroid and hypothyroid rat liver during the regenerative process. In euthyroid rats, the expression of TGF- $\beta 1$ and TßR-II remained constant for up to $12 \mathrm{~h}$ after PH, increased at $24-48 \mathrm{~h}$ by $288 \pm 26 \%$ and $229 \pm 19 \%(\mathrm{P}<0.001)$, respectively, and thereafter slowly returned to basal levels. In hypothyroid rats, TGF- 31 mRNA levels did not change for the first $48 \mathrm{~h}$, increased between 72 and $120 \mathrm{~h}$ with a peak of $277 \pm 19 \%$ at $96 \mathrm{~h}$, and returned to basal levels at $144 \mathrm{~h}$, whereas TßR-II mRNA levels remained constant for up to $6 \mathrm{~h}$ after $\mathrm{PH}$, increased $>2$-folds at 24-48 h, reaching levels similar to those detected in the euthyroid group, and returned to basal levels after a decrease to $52 \pm 8 \%$ at $96 \mathrm{~h}$.

\section{Discussion}

Liver regeneration after $\mathrm{PH}$ provides an excellent in vivo model for studying the role of factors involved in the transition of hepatocytes from a quiescent to a proliferative state and vice versa, when the liver mass has been restored. We have previously reported that hypothyroidism impairs the liver's regenerative capacity after $\mathrm{PH}(17,21)$. The results reported here reveal that this effect involves a delay in hepatocyte 'priming' as well as in stopping proliferative signals.

Activation of immediate early genes characterizes the initiation of hepatocyte proliferation after $\mathrm{PH}$. We show that c-fos and c-myc are expressed in the liver within a few hours following $\mathrm{PH}$, consistently with previous reports $(31,32)$. Expression of these genes is widely assumed to be integral to the hepatic regenerative response as it would lead to the formation of transcription factors that are supposed to play an important role in liver regeneration (33). Previous studies on different liver regenerative models have shown that hepatocyte 'priming' can be variably affected by treatments/conditions that delay or abrogate hepatic cell replication. Dexamethasonetreatment and hypophysectomy, which delay DNA synthesis, (34) or acute hepatic failure, which completely blocks DNA synthesis and hepatocyte proliferation (9), do not cause any 
change in expression of immediate early genes. On the contrary, inhibition of DNA synthesis by retinoic acid in regenerating liver is associated with repression of c-fos and c-jun expression (35). $\mathrm{T}_{3}$ modulates liver growth (36) by regulating the gene expression for a diverse range of cellular pathways, including glycogenolysis, gluconeogenesis, lipogenesis, cell proliferation and apoptosis (37). In this context, it has been reported that hypothyroidism causes a reduction in DNA synthesis, PCNA (proliferating cell nuclear antigen) expression and mitotic activity in the liver after hepatic resection $(20,22,23,38)$. We show here that hypothyroidism significantly delays c-fos and c-myc mRNA expression after $\mathrm{PH}$, suggesting that it might partly exert its antiproliferative activity on liver cells during the 'priming' stage.

We have previously reported that, after chemical induction of hypothyroidism, the regenerative process starts with a liver mass lower than the euthyroid controls $(17,21)$. TGF- 31 can be involved in the control of liver growth, acting as a growth inhibitor of hepatocytes in culture (39), and low levels of TGF- $\beta 1$ mRNA are supposed to maintain the quiescent state of hepatocytes (40). Consistently, we found basal expression of TGF- $\beta 1$ mRNA in the euthyroid liver. The TGF- $\beta 1$ action on liver growth is mediated by TßR-II $(11,41)$ and an increase in TßR-II mRNA expression has been associated with increased sensitivity of hepatocytes to TGF-B1-related growth inhibition (42). We show here that hypothyroidism increases liver TGF- 11 and TßR-II mRNA expression, suggesting that coordinated changes in the expression of TGF- $\beta 1$ as well as of its receptor, TßR-II, could be responsible, at least in part, for the negative regulation of liver growth by a hypothyroid state.

After PH, the liver 'knows' exactly when to stop growing and various studies have been focused on the mechanisms involved in the arrest of liver regeneration $(1,2,6)$. Besides its role as a negative regulator of liver growth, TGF- $\beta 1$ has been proposed as a major candidate regulating the termination of constitutive DNA synthesis in hepatocytes after PH once the functional liver mass has been regained (43). In fact, suppression of TGF- $\beta 1$ expression results in up-regulation of transcripts for regeneration factors and inhibitors of apoptosis (44). Consistent with previous findings $(40,42,45,46)$, we show that, in euthyroid rats, TGF- $\beta 1$ mRNA expression reaches a peak $48 \mathrm{~h}$ after $\mathrm{PH}$, when the liver weight is $\sim 60 \%$ of the initial mass (21). Interestingly, hypothyroidism delays by $72 \mathrm{~h}$ the increase in TGF- 11 mRNA expression, which occurs $96 \mathrm{~h}$ after $\mathrm{PH}$, at which point the liver weight is still $\sim 50 \%$ of the initial mass (21). The rising levels of TGF- 31 mRNA during liver regeneration can act to limit the proliferative response of the hepatocytes through restriction of G1 to $S$ phase cell cycle transition (47). However, the sensitivity to TGF- 31 signaling is dependent on TßR-II expression. We show that, in euthyroid animals, the increase in TGF- 31 mRNA expression is accompanied by an increase in TßR-II levels, which is recognized as being a physiologically important mechanism underlying the termination of liver regeneration (42). In hypothyroid rats, the initial increase in TßR-II mRNA expression is followed by a decrease $96 \mathrm{~h}$ after $\mathrm{PH}$. Because the TGF- $\beta 1$ protein can suppress the expression of TßR-II in hepatocytes (42), it is possible that this decrease in TBR-II mRNA expression may be in part mediated by the increase in hepatic TGF- $\beta 1$ protein. These orchestrated changes in TGF- $\beta 1$ and TßR-II expression could allow the hepatocytes of hypothyroid animals to continue proliferating until the functional liver mass is gained. Indeed, hypothyroid rats are able to regenerate their liver mass completely but the process is significantly delayed, with $\sim 50 \%$ recovery at $96 \mathrm{~h}$ after $\mathrm{PH}$, at which point regeneration is complete in the euthyroid group (21).

In conclusion, our results suggest that an impaired liver regenerative capacity in hypothyroidism after $\mathrm{PH}$ might be due to the delayed expression of genes involved in the control of G0-G1 progression and growth arrest. Since these changes could affect the normal course of liver regeneration and, thus, the liver specific functions in transplantation or following viral infections, future genetic approaches to examine either deleted or enhanced signals of specific gene expression might demonstrate the causal relationship between changes in the expression of positive and negative proliferative regulators and liver diseases in a hypothyroid state. Based on this knowledge, potential therapeutic strategies could be developed.

\section{Acknowledgements}

This work was supported by the MURST-PPRST Cluster 03 grant and the MIUR-Contributi Straordinari di Ricerca/aree obiettivo 1 grant (to E.M.). We are grateful to Professor F. Capuano for helping in the surgical procedure.

\section{References}

1. Michalopoulos GK and De Frances MC: Liver regeneration. Science 276: 60-66, 1997.

2. Bucher NL: Liver regeneration: an overview. J Gastroenterol Hepatol 6: 615-624, 1991.

3. Greco M, Moro L, Pellecchia G, Di Pede S and Guerrieri F: Release of matrix proteins from mitochondria to cytosol during the prereplicative phase of liver regeneration. FEBS Lett 427: 179-182, 1998.

4. Guerrieri F, Pellecchia G, Lopriore B, Papa S, Esterina Liquori G, Ferri D, Moro L, Marra E and Greco M: Changes in ultrastructure and the occurrence of permeability transition in mitochondria during rat liver regeneration. Eur J Biochem 269: 3304-3312, 2002.

5. Ferri D, Moro L, Mastrodonato M, Capuano F, Marra E, Liquori GE and Greco M: Ultrastructural zonal heterogeneity of hepatocytes and mitochondria within the hepatic acinus during liver regeneration after partial hepatectomy. Biol Cell 97: 277-288, 2005.

6. Fausto N: Liver regeneration. J Hepatol 32: 19-31, 2000.

7. Haber BA, Mohn KL, Diamond RH and Taub R: Induction patterns of 70 genes during nine days after hepatectomy define the temporal course of liver regeneration. J Clin Invest 91: 1319-1326, 1993

8. Hui TT, Mizuguchi T, Sugiyama N, Avital I, Rozga J and Demetriou AA: Immediate early genes and p21 regulation in liver of rats with acute hepatic failure. Am J Surg 183: 457-463, 2002.

9. Fausto $\mathrm{N}$ and Mead JE: Regulation of liver growth: protooncogenes and transforming growth factors. Lab Invest 60: 4-13, 1989 .

10. Fausto N, Laird AD and Webber EM: Liver regeneration. 2. Role of growth factors and cytokines in hepatic regeneration. FASEB J 9: 1527-1536, 1995.

11. Romero-Gallo J, Sozmen EG, Chytil A, Russell WE, Whitehead R, Parks WT, Holdren MS, Her MF, Gautam S, Magnuson M, Moses HL and Grady WM: Inactivation of TGFbeta signaling in hepatocytes results in an increased proliferative response after partial hepatectomy. Oncogene 24: 3028-3041, 2005.

12. Alexandrow MG and Moses HL: Transforming growth factor beta and cell cycle regulation. Cancer Res 55: 1452-1457, 1995. 
13. Short J, Brown RF, Husakova A, Gilbertson JR, Zemel R and Lieberman I: Induction of deoxyribonucleic acid synthesis in the liver of the intact animal. J Biol Chem 247: 1757-1766, 1972.

14. Francavilla A, Carr BI, Azzarone A, Polimeno L, Wang Z, van Thiel DH, Subbotin V, Prelich JG and Starzl TE: Hepatocyte proliferation and gene expression induced by triiodothyronine in vivo and in vitro. Hepatology 20: 1237-1241, 1994.

15. Forbes SJ, Themis M, Alison MR, Selden C, Coutelle C and Hodgson HJ: Retroviral gene transfer to the liver in vivo during tri-iodothyronine induced hyperplasia. Gene Ther 5: 552-555, 1998.

16. Oren R, Dabeva MD, Karnezis AN, Petkov PM, Rosencrantz R, Sandhu JP, Moss SF, Wang S, Hurston E, Laconi E, Holt PR, Thung SN, Zhu L and Shafritz DA: Role of thyroid hormone in stimulating liver repopulation in the rat by transplanted hepatocytes. Hepatology 30: 903-913, 1999.

17. Vacca RA, Moro L, Caraccio G, Guerrieri F, Marra E and Greco M: Thyroid hormone administration to hypothyroid rats restores the mitochondrial membrane permeability properties. Endocrinology 144: 3783-3788, 2003.

18. Guerrieri F, Kalous M, Adorisio E, Turturro N, Santoro G, Drahota $\mathrm{Z}$ and Cantatore P: Hypothyroidism leads to a decreased expression of mitochondrial F0F1-ATP synthase in rat liver. $\mathrm{J}$ Bioenerg Biomembr 30: 269-276, 1998.

19. Goglia F, Silvestri E and Lanni A: Thyroid hormones and mitochondria. Biosci Rep 22: 17-32, 2002.

20. Alisi A, Demori I, Spagnuolo S, Pierantozzi E, Fugassa E and Leoni S: Thyroid status affects rat liver regeneration after partial hepatectomy by regulating cell cycle and apoptosis. Cell Physiol Biochem 15: 69-76, 2005.

21. Moro L, Marra E, Capuano F and Greco M: Thyroid hormone treatment of hypothyroid rats restores the regenerative capacity and the mitochondrial membrane permeability properties of the liver after partial hepatectomy. Endocrinology 145: 5121-5128, 2004.

22. Cervinkova Z and Simek J: Effect of propylthiouracil on liver regeneration in rats after partial hepatectomy. Physiol Res 41: 141-146, 1992.

23. Maliekal TT, Sudha B and Paulose CS: Kinetic parameters of Thymidine kinase and DNA synthesis during liver regeneration: role of thyroid hormones. Life Sci 60: 1867-1874, 1997.

24. Chirgwin JM, Przybyla AE, MacDonald RJ and Rutter WJ: Isolation of biologically active ribonucleic acid from sources enriched in ribonuclease. Biochemistry 18: 5294-5299, 1979.

25. Moro L, Greco M, Ditonno P, Battaglia M, Marra E and Perlino E: Transcriptional regulation of the $\beta_{1 C}$ integrin splice variant in human prostate adenocarcinoma. Int J Oncol 23: 1601-1606, 2003.

26. Miller AD, Curran T and Verma IM: c-fos protein can induce cellular transformation: a novel mechanism of activation of a cellular oncogene. Cell 36: 51-60, 1984.

27. Marcu KB, Harris LJ, Stanton LW, Erikson J, Watt R and Croce CM: Transcriptionally active c-myc oncogene is contained within NIARD, a DNA sequence associated with chromosome translocations in B-cell neoplasia. Proc Natl Acad Sci USA 80: 519-523, 1983.

28. Derynck R, Jarrett JA, Chen EY, Eaton DH, Bell JR, Assoian RK, Roberts AB, Sporn MB and Goeddel DV: Human transforming growth factor-beta complementary DNA sequence and expression in normal and transformed cells. Nature 316: 701-705, 1985.

29. Centrella M, Ji C, Casinghino S and McCarthy TL: Rapid flux in transforming growth factor-beta receptors on bone cells. J Biol Chem 271: 18616-18622, 1996.

30. Bhatia P, Taylor WR, Greenberg AH and Wright JA: Comparison of glyceraldehyde-3-phosphate dehydrogenase and 28S-ribosomal RNA gene expression as RNA loading controls for Northern blot analysis of cell lines of varying malignant potential. Anal Biochem 216: 223-226, 1994.
31. Mead JE, Braun L, Martin DA and Fausto N: Induction of replicative competence ('priming') in normal liver. Cancer Res 50: 7023-7030, 1990.

32. Hattori M, Tugores A, Westwick JK, Veloz L, Leffert HL, Karin M and Brenner DA: Activation of activating protein 1 during hepatic acute phase response. Am J Physiol 264: G95-G103, 1993.

33. Taub R: Liver regeneration 4: transcriptional control of liver regeneration. FASEB J 10: 413-427, 1996.

34. Nagy P, Bisgaard HC, Schnur J and Thorgeirsson SS: Studies on hepatic gene expression in different liver regenerative models. Biochem Biophys Res Commun 272: 591-595, 2000.

35. Ozeki A and Tsukamoto I: Retinoic acid repressed the expression of c-fos and c-jun and induced apoptosis in regenerating rat liver after partial hepatectomy. Biochim Biophys Acta 1450: 308-319, 1999.

36. Torres S, Diaz BP, Cabrera JJ, Diaz-Chico JC, Diaz-Chico BN and Lopez-Guerra A: Thyroid hormone regulation of rat hepatocyte proliferation and polyploidization. Am J Physiol 276: G155-G163, 1999.

37. Feng X, Jiang Y, Meltzer P and Yen PM: Thyroid hormone regulation of hepatic genes in vivo detected by complementary DNA microarray. Mol Endocrinol 14: 947-955, 2000.

38. Grattagliano I, Lauterburg BH, Portincasa P, Caruso ML, Vendemiale G, Valentini AM, Palmieri VO and Palasciano G: Mitochondrial glutathione content determines the rate of liver regeneration after partial hepatectomy in eu- and hypothyroid rats. J Hepatol 39: 571-579, 2003.

39. Nakamura T, Tomita Y, Hirai R, Yamaoka K, Kaji K and Ichihara A: Inhibitory effect of transforming growth factor-beta on DNA synthesis of adult rat hepatocytes in primary culture. Biochem Biophys Res Commun 133: 1042-1050, 1985.

40. Braun L, Mead JE, Panzica M, Mikumo R, Bell GI and Fausto N: Transforming growth factor beta mRNA increases during liver regeneration: a possible paracrine mechanism of growth regulation. Proc Natl Acad Sci USA 85: 1539-1543, 1988.

41. Shi Y and Massague J: Mechanisms of TGF-beta signaling from cell membrane to the nucleus. Cell 113: 685-700, 2003.

42. Nishikawa Y, Wang M and Carr BI: Changes in TGF-beta receptors of rat hepatocytes during primary culture and liver regeneration: increased expression of TGF-beta receptors associated with increased sensitivity to TGF-beta-mediated growth inhibition. J Cell Physiol 176: 612-623, 1998.

43. Fausto N, Mead JE, Gruppuso PA and Braun L: TGF-beta in liver development, regeneration, and carcinogenesis. Ann NY Acad Sci 593: 231-242, 1990.

44. Nakamura T, Ueno T, Sakamoto M, Sakata R, Torimura T, Hashimoto O, Ueno H and Sata M: Suppression of transforming growth factor-beta results in upregulation of transcription of regeneration factors after chronic liver injury. J Hepatol 41: 974-982, 2004.

45. Carr BI, Huang TH, Itakura K, Noel M and Marceau N: TGF beta gene transcription in normal and neoplastic liver growth. J Cell Biochem 39: 477-487, 1989.

46. Bissell DM, Wang SS, Jarnagin WR and Roll FJ: Cell-specific expression of transforming growth factor-beta in rat liver. Evidence for autocrine regulation of hepatocyte proliferation. J Clin Invest 96: 447-455, 1995.

47. Oe S, Lemmer ER, Conner EA, Factor VM, Leveen P, Larsson J, Karlsson $\mathrm{S}$ and Thorgeirsson SS: Intact signaling by transforming growth factor beta is not required for termination of liver regeneration in mice. Hepatology 40: 1098-1105, 2004. 